\title{
Squares as tools for urban transformation: Foundations for designing the Iranian public
} squares

Asma Mehan

asma.mehan@polito.it

Politecnico di Torino, Torino, Italy.

\begin{abstract}
The very concept of Public Square as microcosms of urban life and social relations has been transformed dramatically, especially in modern Iran. This article investigates the most dominant foundations, abstract ideas, ideologies and power relations that influenced the Iranian Public Squares' designing. By considering the changing foundations for ideology and power relations, and their impact on urban form, this research follows the history and development of Iranian urbanism. Building on these foundations, it focuses on the transitional history and urban evolution of Iranian public squares through the Politico-religious and modern foundation still the contemporary era. Since the source of power has shifted to a wider mass of people in contemporary era, it can be concluded that designers should consider the social foundations at the time of redevelopment, in other words, the squares needed to be designed for people.
\end{abstract}

KEYWORDS: Public Squares. Iran. Urban Transformation. Modernity. 


\section{INTRODUCTION}

The public squares reveal the life and the historical identity of the cities, while they are constant scenes of urban transformations (MEHAN, 2017). Michael Webb, in his book "The City Square", focused on the necessity of squares as microcosms of urban life. He added that traditionally square has been shaped by commerce and defense, political systems and cultural traditions, climate and topography (WEBB, 1990). On the other hand, the Iranian public squares have traditionally been the focal point of urban life and social interaction. However, under the thrust of technological changes, vehicular traffic and population growth, Iranian historical squares have lost their identity and they are no longer the main social nodes of cities (MEHAN, 2016). This research focuses on connected thoughts and ideologies and connected main foundations and frameworks in urban history of Iranian squares. At the same time, there is a constant tension between context and action, between ideology and power relations, and their impact on urban form. Respectively, this research focuses on the transitional history and urban evolution of Iranian public squares through the Politico-religious and modern foundations till the contemporary era. For searching the very demonstration of ideological and politicoreligious Foundations, formation of a unique spatial configuration of Naghsh-e Jahan Square will be analyzed. Following in modern foundations, the spatial transformation of two historical public squares in Tehran-Baharestan Square and Toopkhaneh (Artillery) Square-is will be introduced.

\section{POLITICO-RELIGIOUS FOUNDATIONS: SQUARES OF SOVEREIGNTY}

For most of human history, the social and spatial order of the cities has been influenced by spiritual basis, which shaped the city (MADANIPOUR, 2007). Gideon suggested that the impact of religion on architecture could be explained by man's desire for a prolongation of life and for a constitution of existence after death in ancient Middle Eastern architecture (GIDEON, 1981). In this sense, the ancient Persian city was also formed on the basis of a marriage of cosmology and temporal power (MADANIPOUR, 2007). The very concept of the city as the imperial capital manifested both ideas of Persian paradiseand Islamic Medina in their greatest manifestation. The Persian city was square shaped, with four gates at four sides connected to each other through two intersecting main axes, a significant southern gate, and raised and walled citadels inside the city (MADANIPOUR, 1998).

The very demonstration of the ideological and religious foundation is manifested in the grand scale urban projects in the time of Shah Abbas (1571-1629), who chose the city of Isfahan as the new capital.Reconstruction of the city of Isfahan is a paradigmatic example of this extensive political project within the boundary of a city. The new master plan of Shah Abbas differentiated the new city from the old historical center by organizing the street patterns on orthogonal grids not oriented toward Mecca. (THAMES; HUDSON, 2003). The grandiose architectural design happened in the formation of a unique spatial configuration of Naghsh-e Jahan Square, whichwas a rectangular space surrounded by bazaars and served as the forecourt to the royal palaces, gardens and mosques and contributed to social and political activities (Fig.1) (WALCHER, 1998). In the traditional IranianPublicSquaresthe same pattern of design of courtyard houses and mosques was followed; they were oriented around a central pool that was an aesthetic center as well as a practical feature for the people who used them

Studies on the morphological, functional, social, and spatial properties of Naghsh-e Jahan Square highlight that there is a dynamic connection between the royal palace (government), city, and society (people). In fact the new square, with its bazaars, mosques and the palace, as well as its open public space dedicated to daily markets, court-sponsored spectacles, material performances, polo and other equestrian sports, 
represents practices of sovereignty and its public-royal interactions. ${ }^{1}$ Therefore the entire square design can be read as the imprint of a spiritual mapping of Sovereignty. ${ }^{2}$

Figure 1- Engraving of the Naghsh-e Jahan Square in Tavernier - The city square is a positive void in Isfahan

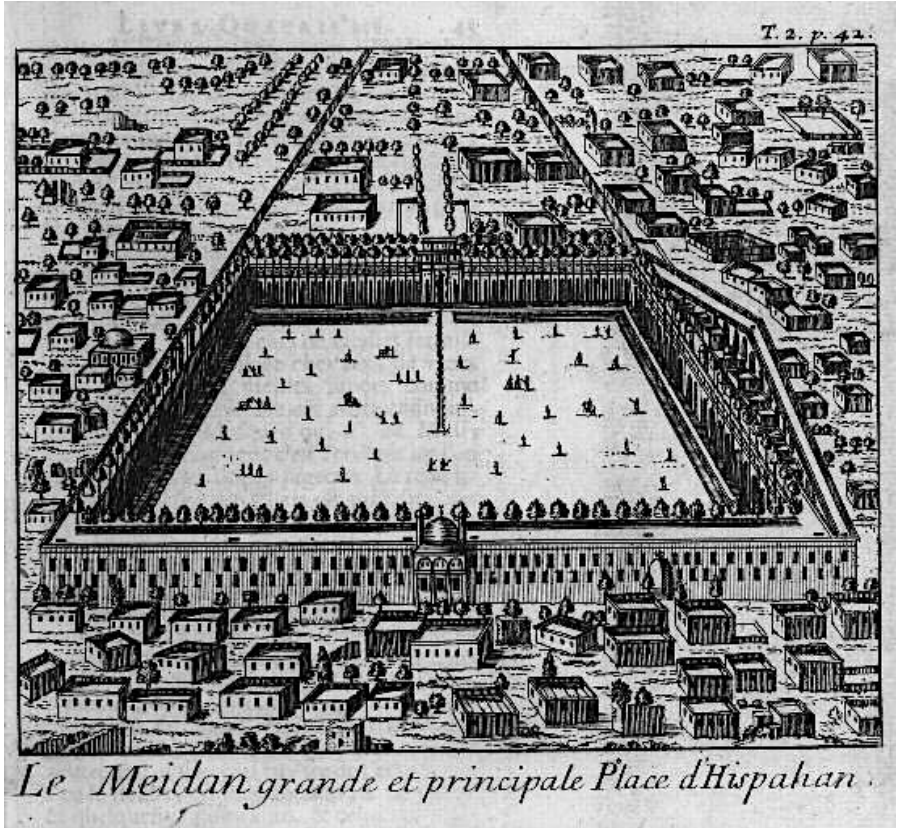

Source: Bibliothèque nationale de France (gallica.bnf.fr)

\section{MODERN FOUNDATIONS: SQUARES OF POWER REASON}

The notion of public is connected to the notion of people in the framework of the nation-state political organization. By reading the city through transformation of public spaces, the relationship between its architecture and political power will be exposed as an example in which the architecture of the city is charged with enabling an ideological interaction through action and reaction, revolution and resistance (MEHAN, 2015).

The traditional patterns of use for public squares were in charge till the modern ages when the kings started to travel to Europe and import the European patterns of city planning and mix them with the traditional layout of the cities (SOLTANI, 2011). In traditionallranian squares, streets entered the space at its corners, leaving the center free for commercial or social activities. However the streets of Renaissance style, entered the square at the middle of its sides, which accommodated traffic and put a visual emphasis on the central point, where a statue or monument could be placed. Therefore, the design of the square was changing according to the principle of central composition, whereby the entire composition revolved around a central point, which now often marked the glory of absolute power. At the city scale, the square was now beginning the role of the central node, connecting a set of geometrically regular streets into a network of transportation and communication.

Tehran, the capital of Iran, has experienced different styles of modernization during the last five decades. In the 1920s and 1930s, the rise of modern architecture in Iran, under the modernist ruling ambitions of Reza Shah, led to shift dramatically from an aristocratic to bourgeois sovereignty (MEHAN, 2017). This was part of seeing the entire city as a single composition rather than a collection of separate parts. The modernization 
project in Tehran as the result of the global economy, similar to some other cities such as Cairo and Istanbul, was associated with several changes to the socio-spatial structure of the city (MIRGHOLAMI, 2009). New Squares, as the new centers of urban activity, were for the fist time filled with figurative sculptures, as an evidence of departure from the past and rupture from the Islam's disapproval of public representation of figures (MAREFAT, 1998). The figures of national heroes or poets, as well as the figures of Reza Shah, replaced the previous pools and gardens of the squares in Tehran, as it can be observed in the images of Toopkhaneh Square (Fig.2). In other words the new squares of the city, were carefully planned open spaces to demonstrate the power of the state and represent its grandeur. Then the squares become the scenes of social demonstrations, political movement and power struggle in the city, as the political demonstrations for nationalizing of oil industry in front of Iranian National Parliament in Baharestan Square (Fig.3) (MEHAN, 2017).

Figure 2 - Reza Shah Statue in Toopkhaneh Square, 1960.

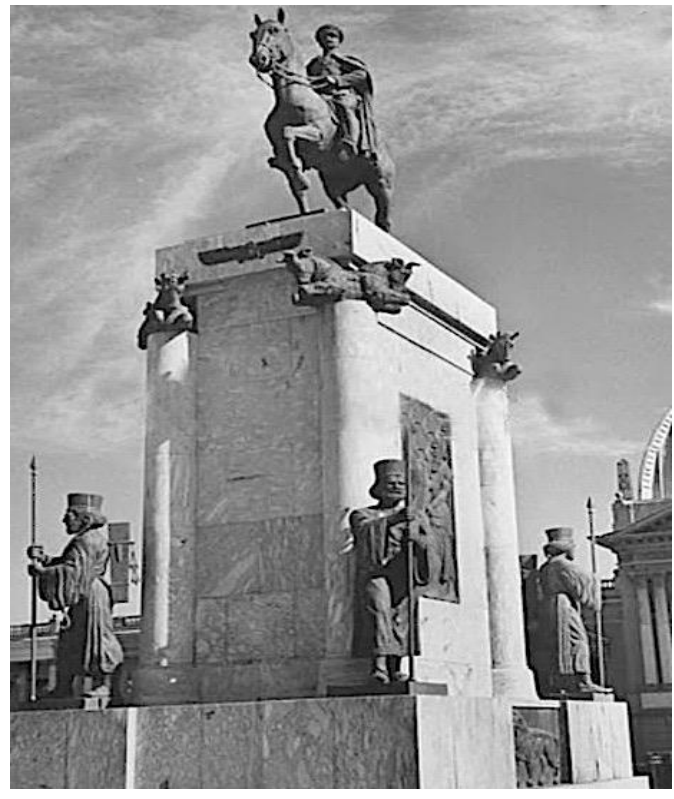

Source: Wikipedia

Figure 3 - Demonstration for nationalizing of oil industry in front of Iranian National Parliament in Baharestan Square.

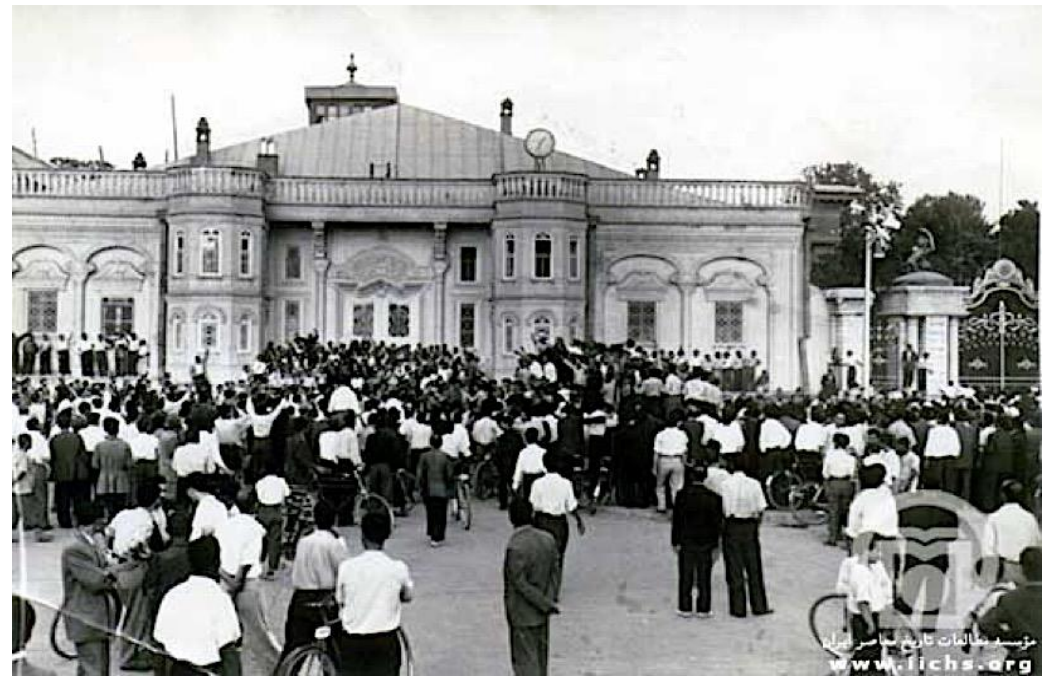

Source: Institute for Iranian Contemporary Historical Studies (www.iichs.ir) 


\section{ESCAPE FROM SQUARE}

Public Squares are fundamental features of cities, which represent sites of sociability, face-to-face interaction and social quality of urban life. The study of Iranian cities from the ancient period especially after the Islamic period indicates that Public squares had always an effective presence in the cities. However, in contemporary Iranian Cities, a common image of Iranian Square is referred to as a type of traffic "Roundabout" which is formed by crossing streets (MEHAN, 2016). Thus, in the last few decades, many Iranian publics quares have lost their function and role due to the transformations in use of public spaces (MEHAN, 2016).

The squares of Tehran lost their function of sociability and transformed into circulation apparatuses and loose their meaning since Reza Shah Pahlavi's period of reign and his westernization programs. When Reza Shah introduced modern new organs to the city, the previous city squares started to loose their meaning. While earlier squares were like medieval open spaces that were evolving in time and covering varieties of public activities, the modern squares were dedicated to power and symbolism. During the second half of 20th century, the public squares of the city, which were once built in a coherent architectural language and were holding crucial commercial, religious and official functions, were almost diminished.

\section{CONCLUSION: SQUARES OF PEOPLE}

Historically, squares were designed and developed in accordance with the representations of kings as the spiritual sources. Major nodes and axes were developed to enhance the position of sources of power in the daily life of the citizens. As the modern democratic societies emerged, the source of power shifted to majority of people, and now the squares needed to be designed for people. Rather than kings, it is now the people who are the source of inspiration for city design.

Explosive pressure for social and political change is a hallmark of modern public squares as it can be seen in Azadi (Freedom Square/Previously Shahyad Square) in demonstrations and Islamic revolution of1978(Fig.4). Moreover, this was also the period of industrialization and urbanization in Iran, in which almost every aspect of social life was undergoing major change. Le Corbusier, in his book,Towards a new architecture offers a choice: 'architecture or revolution', campaigning that socially concerned architecture would prevent a social revolution (CORBUSIER, 1978).

Regarding the fact that people are embedded in various sets of social, political and spatial relationships in the public square, any further change needs to involve them, rather than being imposed on them. 
Figure 4 - Azadi Square during the Islamic Revolution of 1978.

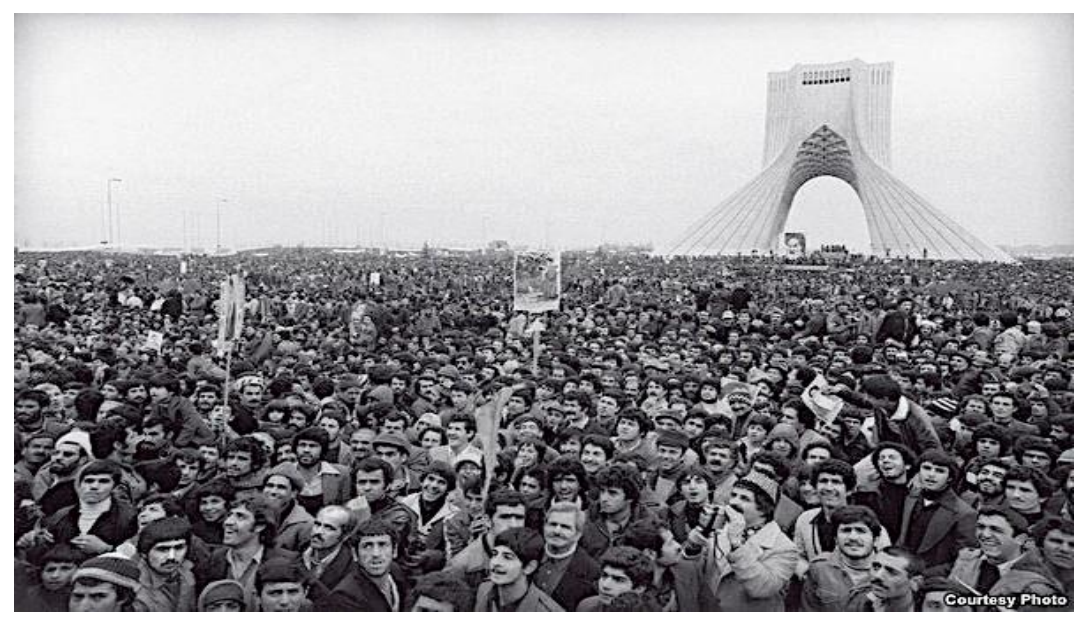

Source: https://foursquaresmovements.wordpress.com/2012/05/01/iranian-revolution1979-shahyadazadi-square-tehran-university/ 


\section{Praças como ferramentas para a transformação urbana: Fundações para projetar as praças públicas iranianas}

RESUMO

O próprio conceito de praça pública como microcosmos de urbanizar relações da vida e sociais, foi transformado dramaticamente, especialmente no Irã moderno. Este artigo investiga as bases mais dominantes, ideias abstratas, ideologias e relações de poder que influenciaram a concepção dos iranianos das praças públicas. Ao considerar os fundamentos, mudança de ideologia e relações de poder eo seu impacto na forma urbana, esta pesquisa segue a história eo desenvolvimento do urbanismo iraniano. Com base nestes fundamentos, centra-se sobre a história de transição e evolução urbana de praças públicas iranianas através das fundações político-religiosa, modernos até a era contemporânea. Desde a fonte do poder deslocou-se a uma massa maior de pessoas em época contemporânea, pode-se concluir que os designers devem considerar os fundamentos sociais no momento da reconstrução, em outras palavras, as praças precisam ser projetado para as pessoas.

PALAVRAS-CHAVE: Praças públicas. Irã. Transformação urbana. Modernidade. 


\section{REFERENCES}

BABAIE, Sussan. Persia: The Safavid 1501-1722. In The Great Empires of Persia, by Jim Masselos, edited by Jim Masselos, 139-235. London: Thames and Hudson, 2010.

GIEDION, Sigfried. The beginnings of architecture. Princton University Press, 1981.

LECORBUSIER. Towards a New Architecture. London: The Architectural Press, 1978.

MADANIPOUR, Ali. Designin the City of Reason: Foundations and Frmeworks. London and New York: Routledge: Tyler \& Francis Group, 2007.

MADANIPOUR, Ali. Tehran: The making of a Metropolis. Willey, 1998.

MAREFAT, Mina. Building to power: Architecture of Tehran 1921-1941. Massachusetts Institute of Technology, 1988.

MEHAN, Asma. Architecture for Revolution: Democracy and Public space. Graduate Student Forum, Edinburgh College of Art, University of Edinburgh, Edinburgh: Society of Architectural Historians of Great Britain (SAHGB) , 2015.

MEHAN, Asma. Manifestation of Modernity in Iranian Public Squares: Baharestan Square. International Journal of Heritage Architecture (WIT Press) 1, no. 3 (2017 ): 411-420. DOI: 10.2495/HA-V1-N3-411-420

MEHAN, Asma. Public Squares and Their Potential for Social Interactions: A Case Study of Historical Public Squares in Tehran.International Journal of Architectural and Environmental Engineering (World Academy of Science, Engineering and Technology) Vol. 10, No. 2 (2016): 489-494 . DOI: scholar.waset.org/1999.10/10003692

MEHAN, Asma. Urban Regeneration: A Comprehensive Strategy For Achieving Social Sustainability in Historical Squares.3rd INTERNATIONAL MULTIDISCIPLINARY SCIENTIFIC CONFERENCE ON SOCIAL SCIENCES AND ARTS S G E M 201 6. Vienna: STEF92 Technology Ltd., 51 lexander Malinov 12 Sofia, Bulgaria, 2016. 862-868. spaces in Tehran. Melbourn : The University of Melbourn, 2009. 
SOLTANI, Zohreh. TheTransformation of public space: City Squares as Locations for Power Struggle - The Case of Tehran (1934-2009). PhD Thesis, Middle East Technical University, 2011.

WALCHER, Heidi A. Between Paradise and Political Capital: The Semiotics of Safavid Isfahan .Middle Eastern Natural Environment (Yale F\&ES Bulletin) 1 (1998): 330.

WEBB, Michael. The City Square. London: Thames and Hudson , 1990.

Como citar: MEHAN, A. Squares as tools for urban transformation: Foundations for designing the Iranian public squares. R. bras. Planej. Desenv., Curitiba, v. 5, n. 2, p. 246-254, mai./ago. 2016. Disponível em: $<$ https://periodicos.utfpr.edu.br/rbpd>. Acesso em: XXX.

Correspondência:

Asma Mehan

Corso Duca degli Abruzzi, 24, 10129 Torino, Itália.

Direito autoral: Este artigo está licenciado sob os termos da Licença CreativeCommons-Atribuição 4.0 Internacional.

\section{(c) (1)}

